\title{
Correction to: How Nations Succeed
}

\section{Correction to:}

M. A. Yülek, How Nations Succeed, https://doi.org/10.1007/978-981-13-0568-9

The original version of this book was revised because belated corrections were done to the text by the Author.

The updated online version of this book can be found at https://doi.org/10.1007/978-981-13-0568-9 